\title{
Etiologic analysis of 100 anatomically failed dacryocystorhinostomies
}

This article was published in the following Dove Press journal:

Clinical Ophthalmology

28 July 2016

Number of times this article has been viewed

Tarjani Vivek Dave

Faraz Ali Mohammed

Mohammad Javed Ali

Milind N Naik

The Institute of Dacryology, LV Prasad Eye Institute,

Hyderabad, India
Correspondence: Mohammad Javed Ali

The Institute of Dacryology, L V Prasad Eye Institute, Road No 2, Banjara Hills, Hyderabad 34, India

Tel +9l $40306 \mid$ 2345/26I2

Email drjaved007@gmail.com
Background: The aim of this study was to assess the etiological factors contributing to the failure of a dacryocystorhinostomy (DCR).

Patients and methods: Retrospective review was performed in 100 consecutive patients who were diagnosed with anatomically failed DCR at presentation to a tertiary care hospital over a 5-year period from 2010 to 2015. Patient records were reviewed for demographic data, type of past surgery, preoperative endoscopic findings, previous use of adjuvants such as intubation and mitomycin $\mathrm{C}$, and intraoperative notes during the re-revision. The potential etiological factors for failure were noted.

Results: Of the 100 patients with failed DCRs, the primary surgery was an external DCR in 73 and endoscopic DCR in 27 patients. Six patients in each group had multiple revisions. The mean ages at presentation in the external and endoscopic groups were 39.41 years and 37.19 years, respectively. All patients presented with epiphora. The most common causes of failure were inadequate osteotomy $(69.8 \%$ in the external group and $85.1 \%$ in the endoscopic group, $P=0.19)$ followed by inadequate or inappropriate sac marsupialization $(60.2 \%$ in the external group and $77.7 \%$ in the endoscopic group, $P=0.16$ ) and cicatricial closure of the ostium (50.6\% in the external group and 55.5\% in the endoscopic group, $P=0.83$ ). The least common causes such as ostium granulomas and paradoxical middle turbinate $(1.37 \%, \mathrm{n}=1)$ were noted in the external group only.

Conclusion: Inadequate osteotomy, incomplete sac marsupialization, and cicatricial closure of the ostium were the most common causes of failure and did not significantly differ in the external and endoscopic groups. Meticulous evaluation to identify causative factors for failure and addressing them are crucial for subsequent successful outcomes.

Keywords: failed DCR, etiologies, cicatricial closure, osteotomy, endoscopy

\section{Introduction}

Dacryocystorhinostomy (DCR) is commonly performed by an external or endoscopic approach for managing nasolacrimal duct obstructions, with high success rates. ${ }^{1-7}$ However, failures have been reported in up to $12 \%$ of the patients. ${ }^{1-10}$ Endoscopic evaluation of failed cases may show many possible causes of tear drainage failure and include cicatricial ostium closures, scarred common canaliculus, obstructed distal canaliculi, organizing granulomas, and bone neogenesis. ${ }^{2,11-22}$ The intraoperative surgical causes that may lead or contribute to subsequent failures include inability to correctly localize the sac, inappropriate osteotomy, inadequate sac opening, significant septal deviations, and concha bullosa. ${ }^{2,11-21}$ The present study reports the causes of failures in 100 consecutive patients who presented with anatomical failure of a previously performed external or endoscopic dacryocystorhinostomy. 


\section{Patients and methods}

A retrospective review was performed in 100 consecutive patients who were diagnosed with anatomically failed dacryocystorhinostomy at presentation to a tertiary care hospital over a 5-year period from 2010 to 2015. Approval from the Institutional Review Board of L V Prasad Eye Institute was obtained. Patient consent was deemed not required since this was a retrospective review. Patient records were reviewed for demographic data, type of past surgery, preoperative endoscopic findings, previous use of adjuvants such as intubation and mitomycin $\mathrm{C}$, and intraoperative notes during the re-revision. The potential etiological factors for failure were assessed as mentioned in the notes of nasal endoscopy or intraoperative findings of causes of failure while revising the case. Anatomical failure was defined as nonpatency of ostium on irrigation. Inadequate osteotomy was defined as bone removal, which failed to completely expose the lacrimal sac including its fundus. Inappropriate ostium location or ostium malposition was defined as limited osteotomy, localized inferiorly, anteriorly, or posteriorly in relation to the internal common opening. Inappropriate sac marsupialization was defined as failure to achieve full-thickness sac wall cut along its entire length and failure to reflect the lacrimal sac flaps, noted intraoperatively. Intergroup " $P$ " values were calculated to assess if the approaches had any impact on the outcomes. A $P$-value of $<0.05$ was considered significant.

\section{Results}

Of the 100 patients with failed DCRs at presentation, the primary surgery was an external DCR in 73 and endoscopic DCR (mechanical and powered) in 27 patients. All patients had only one surgery except six patients in each group who underwent one revision before presentation. The mean ages at presentation in the external and endoscopic groups were 39.41 years ( $\mathrm{SD}= \pm 16.17$ years) and 37.19 years $(\mathrm{SD}= \pm 13.62$ years), respectively. All patients presented with epiphora and $73 \%$ $(n=73)$ had associated discharge. The median duration for onset of symptoms following primary surgery for external and endoscopic groups was 12 months and 24 months ( $P=0.33$ ), respectively. The commonest causes of failure were inadequate osteotomy ( $69.8 \%$ in the external group and $85.1 \%$ in the endoscopic group, $P=0.19$ ) followed by inadequate or inappropriate sac marsupialization $(60.2 \%$ in the external group and $77.7 \%$ in the endoscopic group, $P=0.16$ ) and cicatricial closure of the ostium (50.6\% in the external group and $55.5 \%$ in the endoscopic group, $P=0.83$; Table 1 ). Cases with cicatricial closures could be easily identified in preoperative diagnostic nasal endoscopy, whereas inadequate
Table I Failed dacryocystorhinostomy analysis

\begin{tabular}{|c|c|c|c|}
\hline Parameter & $\begin{array}{l}\text { External group } \\
(n=73)\end{array}$ & $\begin{array}{l}\text { Endoscopic } \\
\text { group }(n=27)\end{array}$ & $\begin{array}{l}\text { Intergroup } \\
\text { "P" value }\end{array}$ \\
\hline \multirow[t]{2}{*}{ Sex } & $M=22(30.1 \%)$ & $M=9(33.3 \%)$ & 0.9 \\
\hline & $\mathrm{F}=5 \mathrm{I}(69.9 \%)$ & $F=18(66.6 \%)$ & \\
\hline $\begin{array}{l}\text { Mean age } \\
\text { (years) } \pm S D\end{array}$ & $39.41 \pm 16.17$ & $37.19 \pm 13.62$ & 0.52 \\
\hline Total PLS & 79 (6 - AddI Rev) & 33 (6 - Addl Rev) & \\
\hline Non Dy ICO & $100 \%(n=73)$ & $100 \%(n=27)$ & \\
\hline Neg FEDT & $100 \%(n=73)$ & $100 \%(n=27)$ & \\
\hline \multicolumn{4}{|l|}{ Etiologies } \\
\hline Ost Cic Clos & $50.6 \%(n=37)$ & $55.5 \%(n=15)$ & 0.83 \\
\hline $\mathrm{CCO}$ & $27.3 \%(n=20)$ & $22.2 \%(n=6)$ & 0.79 \\
\hline IN Syn & $23.2 \%(n=17)$ & $44.4 \%(n=12)$ & 0.06 \\
\hline Ost Sten & $30.1 \%(n=22)$ & $22.2 \%(n=6)$ & 0.59 \\
\hline DNS & $10.9 \%(n=8)$ & $14.8 \%(n=4)$ & 0.85 \\
\hline In Ost Siz & $69.8 \%(n=5 I)$ & $85.1 \%(n=23)$ & 0.19 \\
\hline Ost Malp & $19.1 \%(n=14)$ & $29.6 \%(n=8)$ & 0.39 \\
\hline In Sac Mar & $60.2 \%(n=44)$ & $77.7 \%(n=21)$ & 0.16 \\
\hline Int Ethm & $6.8 \%(n=5)$ & $7.4 \%(n=2)$ & 0.7 \\
\hline Org ICO Gr & $1.37 \%(n=1)$ & None & \\
\hline Gr Lat MT & $1.37 \%(n=1)$ & None & \\
\hline
\end{tabular}

Abbreviations: Addl Rev, additional revisions; M, male; F, female; PLS, prior lacrimal surgeries; non Dy ICO, nondynamic internal common opening; Neg FEDT, negative fluorescein endoscopic dye test; Ost Cic Clos, Cicatricial closure of ostium; CCO, common canalicular obstruction; IN Syn, intranasal synechia; Ost Sten, ostium stenosis; DNS, deviated nasal septum; In Ost Siz, inadequate ostium size; Ost Malp, ostium malposition; In Sac Mar, inadequate sac marsupialization; Int Ethm, intervening ethmoids; $\operatorname{Org} \mathrm{ICO} \mathrm{Gr}$, organized internal common opening granuloma; Gr Lat MT, gross lateralization of middle turbinate; SD, standard deviation.

osteotomy and inadequate marsupialization were identified intraoperatively during the revision surgery. The least prevalent causes were internal common opening granuloma and grossly lateralized middle turbinate causing ostium obstruction $(1.37 \%, n=1)$. Both these were noted in only a single case of external DCR. Table 1 lists out all the causes of failures and their frequencies. All the causes do not add up to $100 \%$ since all patients had multiple potential causes of failure. The intergroup " $P$ " values for the demographics and causes of failure were not significantly different between the external and endoscopic groups; however, the total number of cases in the endoscopic group was low.

\section{Discussion}

The present study reports the most common and the rare causes of a dacryocystorhinostomy failure and defines what would constitute the commonest causes found such as inadequate osteotomy, inadequate sac marsupialization, and ostium malpositions. The study also demonstrated no statistically significant differences in the frequencies of causes of failures between the external and endoscopic approaches.

Welham and Wulc ${ }^{13}$ in their series of 204 patients of failed external DCRs showed inadequate ostium size or location 
to be the commonest cause of failure $(54.4 \%, 111 / 204)$ followed by common canalicular obstruction $(52.9 \%$, 108/204). Other causes in their series include rhinostomy scarring $(13.7 \%, 28 / 204)$, intervening ethmoids $(7.35 \%$, $15 / 204)$, sump syndromes $(4.9 \%, 10 / 204)$, active systemic disease $(3.43 \%, 7 / 204)$, and DCR to air cell $(2.9 \%, 6 / 204)$. However, the difference between an intervening ethmoid and DCR to air cell was unclear and other intranasal factors were not considered. In addition, the present study examined the patients endoscopically, defined and analyzed different ostium factors such as size, location, and adequacy separately and included only the pure cohort of anatomical failures following a DCR.

Demarco et $\mathrm{al}^{14}$ studied eleven endoscopic revision surgeries in ten patients of failed external DCR. Inadequate osteotomy (40\%), obstructive septal deviations (30\%), synechia $(20 \%)$, and granulomas $(10 \%)$ were observed to be the causes of failure. Joshi ${ }^{21}$ studied 50 patients of failed transcanalicular DCR and found inadequate osteotomy in 21 patients, unseen osteotomy site in ten, and common canalicular obstruction in three patients. Two patients each showed organized granulomas, osteotomies $5 \mathrm{~mm}$ below the fundus, and neo-osteogenesis. Onerci et a ${ }^{12}$ observed granulation tissue as the common cause of failure (4/6) among experienced surgeons and inappropriate ostium location $(6 / 21)$ and intervening bony spicules $(5 / 21)$ as the common causes among the inexperienced surgeons. The present study showed inadequate osteotomies as the commonest cause of failure accounting for $\sim 70 \%$ in the external group and $85 \%$ in the endoscopic groups.

Cicatricial closure of the ostium has been considered to be the most common cause of DCR failure in the literature. Narioka et al $^{17}$ studied 15 cases of failed external DCRs and found all of them to have the rhinostomy closure with 13 patients showing obstruction at common canaliculus or common canaliculus-sac junction. Four patients had granulation tissue at the rhinostomy site but were not found to be significant to cause the surgical failure. Two patients had additional canalicular obstruction. Choussy et a ${ }^{18}$ studied very long-term follow-up results of endoscopic revision DCRs in 17 patients and reported ostium scarring in 76.4\% $(n=13)$ and unsuitable ostium location in 17.6\% $(n=3)$. Hull et $\mathrm{l}^{19}$ studied 19 consecutive failed DCR in 17 patients, who previously underwent external (46\%), endoscopic (46\%), or endolaser (8\%) approaches. The most common cause for failed DCR was blocked ostium due to scarring in $74 \%$. Appropriately half of the patients $(47.3 \%, 9 / 19)$ had multiple causes of failures. Other causes noted include distal canalicular block (26\%), sump syndrome (21\%), inadequate osteotomy (16\%), middle turbinate abnormalities (11\%), and high ostium (5\%). McMurray et $\mathrm{al}^{22}$ found common canalicular obstructions $(84.6 \%, 11 / 13)$ to be the commonest cause of late ( $>12$ months) failures of dacryocystorhinostomy. Although the present study found cicatricial closures in half of the patients, it was not the commonest cause in this cohort.

Paik et a ${ }^{20}$ reported significant septal deviations and middle turbinate hypertrophies to be more $(P=0.001)$ in cases of previous external DCR when compared with endoscopic DCRs. The present study did not find any significant differences between the external and the endoscopic groups with relation to significant deviated nasal septum $(P=0.85)$. Liang et $\mathrm{al}^{2}$ studied 25 revision endoscopic DCRs and found that the viable agger nasi cell reflects inappropriate sac localization and inadequate sac exposure during the primary surgery and hence contributes to the surgical failure. Intervening ethmoids were noted in $6.8 \%$ of the external and $7.4 \%$ of the endoscopic failures in the current series.

Anatomic studies by Wormald et $\mathrm{al}^{23}$ accurately defined the intranasal location of lacrimal sac and this together with the recent evidence ${ }^{24,25}$ on long-term successful outcomes of endoscopic surgeries as well as the need for adjuvant endoscopic procedures clearly supports the findings of the present study. The keys for successful outcomes in a dacryocystorhinostomy include precise localization of the sac, adequate osteotomy sufficient to expose the entire lacrimal sac including the fundus, full-length marsupialization of the sac, and mucosa-to-mucosa approximation to facilitate healing by primary intention without scarring.

The limitations of this study include lack of accurate details of primary surgery for many patients including the level of expertise of primary surgeon, techniques, and use of adjuvants such as intubation and mitomycin $\mathrm{C}$ and hence hindered a meaningful analysis of this aspect. However, the strengths of the surgery are focused and uniform endoscopic and intraoperative analysis of the etiological factors of a DCR failure in a large consecutive and pure cohort of anatomical failures.

\section{Conclusion}

Inadequate osteotomy, incomplete sac marsupialization, and cicatricial closure of the ostium were the commonest causes of failure and did not significantly differ in the external and endoscopic groups. Meticulous endoscopic evaluation to identify causative factors for failure and addressing them are crucial for subsequent successful outcomes. 


\section{Acknowledgment}

Mohammad Javed Ali receives royalties from Springer for his text book "Principles and Practice of Lacrimal Surgery".

\section{Disclosure}

The authors report no conflicts of interest in this work.

\section{References}

1. Tsirbas A, David G, Wormald PJ. Mechanical endonasal dacryocystorhinostomy versus external dacryocystorhinostomy. Ophthal Plast Reconstr Surg. 2004;20(1):50-56.

2. Liang J, Hur K, Merbs SL, Lane AP. Surgical and anatomic considerations in endoscopic revisions of failed external dacryocystorhinostomy. Otolaryngol Head Neck Surg. 2014;150(5):901-905.

3. Ali MJ, Singh M, Chisty N, Kamal S, Naik MN. Endoscopic ultrasonic dacryocystorhinostomy: clinical profile and outcomes. Eur Arch Otorhinolaryngol. 2016;273(7):1789-1793.

4. Lee DW, Chai CH, Loon SC. Primary external dacryocystorhinostomy versus primary endonasal dacryocystorhinostomy: a review. Clin Experiment Ophthalmol. 2010;38(4):418-426.

5. Xue K, Mellington FE, Norris JH. Meta-analysis of the adjunctive use of mitomycin $\mathrm{C}$ in primary and revision, external and endoscopic dacryocystorhinostomy. Orbit. 2014;33(4):239-244.

6. Ali MJ, Psaltis AJ, Murphy J, Wormald PJ. Outcomes in primary powered endoscopic dacryocystorhinostomy: comparison between experienced versus less experienced surgeons. Am J Rhinol Allergy. 2014; 28(6):514-516.

7. Barnes EA, Abou-Rayyah Y, Rose GE. Pediatric dacryocystorhinostomy for nasolacrimal duct obstruction. Ophthalmology. 2001;108(9): $1562-1564$.

8. Wormald PJ, Roithmann R. Endoscopic and external dacryocystorhinostomy - which is better? Braz J Otorhinolaryngol. 2012;78(6):2.

9. Balikoglu-Yilmaz M, Yilmaz T, Taskin U, et al. Prospective comparison of 3 dacryocystorhinostomy surgeries: external versus endoscopic versus transcanalicular multidiode laser. Ophthal Plast Reconstr Surg. 2015;31(1):13-18.

10. Feng YF, Cai JQ, Zhang JY, Han XH. A meta-analysis of primary dacryocystorhinostomy with and without silicone intubation. Can J Ophthalmol. 2011;46(6):521-527.
11. Elmorsy SM, Fayk HM. Nasal endoscopic assessment of failure after external dacryocystorhinostomy. Orbit. 2010;29(4):197-201.

12. Onerci M, Orhan M, Ogretmenoglu O, Irkec M. Long-term results and reasons for failure of intranasal endoscopic dacryocystorhinostomy. Acta Otolaryngol. 2000;120(2):319-322.

13. Welham RAN, Wulc AE. Management of unsuccessful lacrimal surgery. Br J Ophthalmol. 1987;71(2):152-157.

14. Demarco R, Strose A, Araujo M, et al. Endoscopic revision of external DCR. Otolaryngol Head Neck Surg. 2007;137(3):497-499.

15. Ari S, Kürşat Cingü A, Sahin A, Gün R, Kiniş V, Caça I. Outcomes of revision external dacryocystorhinostomy and nasal intubation by bicanalicular silicone tubing under endonasal endoscopic guidance. Int J Ophthalmol. 2012;5(2):238-241.

16. El-Guindy A, Dorgham A, Ghoraba M. Endoscopic revision surgery for recurrent epiphora occurring after external dacryocystorhinostomy. Ann Otol Rhinol Laryngol. 2000;109(4):425-430.

17. Narioka J, Ohashi Y. Transcanalicular-endonasal semiconductor diode laser-assisted revision surgery for failed external dacryocystorhinostomy. Am J Ophthalmol. 2008;146(1):60-68.

18. Choussy O, Retout A, Marie JP, Cozlean A, Dehisdin D. Endoscopic revision of external dacryocystorhinostomy failure. Rhinology. 2010; 48(1):104-107.

19. Hull S, Lachlan SA, Olver JM. Success rates in powered endonasal revision surgery for failed dacryocystorhinostomy in a tertiary referral center. Ophthal Plast Reconstr Surg. 2013;29(4):267-271.

20. Paik JS, Cho WK, Yang SW. Comparison of endoscopic revision for failed primary external versus endoscopic dacryocystorhinostomy. Clin Experiment Ophthalmol. 2013;41(2):116-121.

21. Joshi RS. Conventional dacryocystorhinostomy in a failed trans-canalicular laser-assisted dacryocystorhinostomy. Indian J Ophthalmol. 2011; 59(5):383-385.

22. McMurray CJ, McNab AA, Selva D. Late failure of dacryocystorhinostomy. Ophthal Plast Reconstr Surg. 2011;27(2):99-101.

23. Wormald PJ, Kew J, Van Hasselt CA. The intranasal anatomy of nasolacrimal sac in endoscopic dacryocystorhinostomy. Otolaryngol Head Neck Surg. 2000;123(3):307-310.

24. Ali MJ, Psaltis AJ, Bassiouni A, Wormald PJ. Long-term outcomes in primary powered endoscopic dacryocystorhinostomy. Br JOphthalmol. 2014;98(12):1678-1680.

25. Ali MJ, Psaltis AJ, Wormald PJ. Long-term outcomes in revision powered endoscopic dacryocystorhinostomy. Int Forum Allergy Rhinol. 2014;4(12):1016-1019.
Clinical Ophthalmology

\section{Publish your work in this journal}

Clinical Ophthalmology is an international, peer-reviewed journal covering all subspecialties within ophthalmology. Key topics include: Optometry; Visual science; Pharmacology and drug therapy in eye diseases; Basic Sciences; Primary and Secondary eye care; Patient Safety and Quality of Care Improvements. This journal is indexed on Submit your manuscript here: http://www.dovepress.com/clinical-ophthalmology-journal

\section{Dovepress}

PubMed Central and CAS, and is the official journal of The Society of Clinical Ophthalmology (SCO). The manuscript management system is completely online and includes a very quick and fair peer-review system, which is all easy to use. Visit http://www.dovepress.com/ testimonials.php to read real quotes from published authors. 